\title{
Removing the Bars for Collaborative Shakespeare
}

\section{Pamela J. Monaco}

\section{(2) OpenEdition \\ Journals}

Electronic version

URL: http://journals.openedition.org/shakespeare/4630

DOI: $10.4000 /$ shakespeare.4630

ISSN: 2271-6424

\section{Publisher}

Société Française Shakespeare

\section{Electronic reference}

Pamela J. Monaco, "Removing the Bars for Collaborative Shakespeare », Actes des congrès de la Société française Shakespeare [Online], 37 | 2019, Online since 07 March 2019, connection on 30 April 2019. URL : http://journals.openedition.org/shakespeare/4630; DOI : 10.4000/shakespeare.4630

This text was automatically generated on 30 April 2019.

(C) SFS 


\title{
Removing the Bars for Collaborative Shakespeare
}

\author{
Pamela J. Monaco
}

12016 found Shakespeare alive and celebrated in Chicago. In honor of the 400-year anniversary of his death, the city declared it the year of Shakespeare, resulting in yearlong festival in which 1.1 million people took part in 863 events across 231 locations in the city. ${ }^{1}$ These were not just theatre events but also included radio shows, lectures, ballets, operas, puppet shows and even a restaurant event called the Culinary Complete Works: 38 PLAYS. 38 CHEFS. ${ }^{2}$ This type of celebration aims to make Shakespeare accessible to all, yet suggest to non-scholar Americans that they should read one of Shakespeare's plays or see one of the plays in the theatre, and the response will not be enthusiastic. Sometimes this tepid response even comes from surprising sources, including our own students. Few colleges and universities in the U.S. require Shakespeare in the curriculum, even for English majors, resulting in many students seeking a degree in literature dismissing the value of knowing Shakespeare's plays.

During the spring 2016 semester, I taught the senior seminar course for English majors at North Central College, a small, private, liberal arts college serving about 3,000 undergraduate students located in a suburb outside Chicago. The college attracts students primarily from a distance of about a 200-mile radius, and few of the students are from urban areas. Many of the students live at home, and $40 \%$ of the students are first generation college students. The professor who teaches the seminar chooses the topic, so I chose Shakespeare, focused on the themes of power and justice. In the class of twenty, nineteen of them women, one-third of the students confessed to not liking Shakespeare. Only three said they really enjoyed the playwright, and the rest were noncommittal. Some of the students had followed me to this class, some had to take the seminar as graduating seniors, and some believed no other seminar would be any better. I faced some challenges.

3 My students brought to the course poor experiences with Shakespeare in the past. Although none of my students attended the same high school, they appeared to have been victims of a common curriculum that favored Romeo and Juliet, Macbeth, and Midsummer 
Night's Dream. They described sitting in their seats and reading plays aloud, watching the Zeffirelli film, finding the language off-putting, and not enjoying the subjects at all. None of these plays were on the seminar syllabus, and of six learning outcomes, three were paramount for me: articulate a nuanced definition of power and justice as revealed through an understanding of Shakespeare's plays throughout time; argue the relevance of Shakespearean theatre to our $21^{\text {st }}$ century lives; and approach Shakespeare without fear and loathing.

Because of my own background in theatre and my decision to teach the class around the theme of power and justice, the course focused on understanding the texts as scripts and comprehending the transition from page to stage. The plays were a combination of history plays, so-called problem plays, comedies and tragedies: Othello, As You Like It, Antony and Cleopatra, I Henry IV, Merchant of Venice, and The Tempest. We watched clips of both classic and recent productions from the RSC, the National Theatre, and Chicago Shakespeare Theatre. ${ }^{3}$ We also went to see The Tempest through an NT Live production, and we studied adaptations and appropriations, including Margaret Atwood's Hagseed. ${ }^{4}$ It is this last part, appropriations and adaptations that this essay explores. In particular, the essay espouses a pedagogical strategy that sheds light on a crucial Shakespearean arts program that builds new audiences, demonstrates the value of Shakespeare for all people, and when combined through university instruction, develops students into more empathetic citizens. In order to provide a context for Shakespeare theatre programs, a brief overview of this movement and its impact on the incarcerated will be provided and woven in as appropriate to illustrate the ways in which these programs not only transform lives of the inmates but also those who view these productions.

Over a decade ago, I taught a course like this at University of Maryland University College to a class of working adults. As part of this class, I brought in the DVD of Shakespeare Behind Bars, which had just been released. Shakespeare Behind Bars is a prison arts program at the Luther Luckett Correctional Complex in LaGrange KY, founded in 1995 by Curt Tofteland. In 2003, a documentary was made of the inmates' process and yearlong work that culminated in a performance at the complex of The Tempest; this documentary was publically released in $2006 .{ }^{5}$ The adult students I taught found this film particularly moving and inspirational. As one student, Carl, a carpenter for the Metro system said, "I will never again complain that something is too hard and I can't learn it." I brought this experience, which was an add-on to my course at the time, to my decision to not only show the film but to actively engage these students with Shakespeare in prison. My pedagogy follows Tofteland's premise for his work within prisons, "if you educated the human mind without educating the human heart, you have educated only half the human being." 6 Bringing my students to an experience of Shakespeare behind bars would, I theorized, connect students to Shakespeare's works by also building a relationship to a hidden segment of American society. On this journey, we would also discover how texts of over 400 years of age release us from our preconceived ideas about others as we witness literal transformations.

\section{Prison Populations}

6 In 2017 the U.S. incarcerated over 2.3 million people, including in jails, juvenile correction facilities, military prison, and state and federal prisons. ${ }^{7}$ As of the end of 2013, the latest year for accurate numbers, the incarceration rate of the United States of 
America was the highest in the world. The United States represents less than $5 \%$ of the world's population, yet it houses around $22 \%$ of the world's prisoners. As of 2015, 126,000 state and federal prisoners were housed in privately operated prisons in the U.S., constituting $7 \%$ of state prisoners and $18 \%$ of federal prisoners. ${ }^{8}$ Privatizing incarceration generates revenue, but it has done nothing to help ensure that inmates released from prison are prepared to be functional citizens. Within three years of release from any prison facility, about two-thirds (67.8\%) of released prisoners were rearrested. That number increases to over $75 \%$ of all released prisoners within five years. ${ }^{9}$ One could argue the benefit of the arts to reducing the number of people incarcerated, but this paper suggests that prison theatre programs, and Shakespeare prison programs in particular, can be instrumental in reducing the recidivism rates while simultaneously introducing new readers, performers, and audiences to Shakespeare's plays. Nationwide, the recidivism rates of the inmates who participate in these programs hovers between $5-7 \%{ }^{10}$ Too often prison exacerbates the traits and behaviors that contributed to criminal behavior; separated from others and prepared to protect oneself from the dangers of inmate life, prisoners build additional barriers to developing empathy and concern for others. Those who participate in Shakespeare prion programs have demonstrated good behavior, and through the rehearsal and performance process, they learn to trust others, to begin to understand people, and to develop ownership of one's actions and forgiveness toward self and others. Shakespeare prison programs achieve the goals of prisonrehabilitation-while helping men and women discover their humanity as they use the acting experience to transform their outlook and behavior.

\section{Shakespeare in the Prisons}

7 This history of carceral programs can be traced to Australia in 1788 when a member of the crew of the Scarborough made note in his diary of the convicts performing songs and skits. In America, the first documented prison production occurred at San Quentin prison in San Francisco in 1910, but most associate U.S. prison theater with the famous production of Waiting for Godot performed by the San Francisco Actor's Workshop in 1957. This marked one of the first times a professional theatre group, the Actor's Workshop, had performed for inmates in a high security prison, but equally noteworthy was the reaction..$^{11}$ Theater audiences and critics who had seen Waiting for Godot had often found the play puzzling, ${ }^{12}$ but the prisoners saw this experience as akin to their own, for their lives behind bars seemed rift with absurdity as they waited for time to pass. Throughout the 1960s and 70s, arts programs in prisons flourished, but the "tough on crime" stance of the Reagan administration eliminated many programs, and the eradication of federal funding for prison education during the Clinton administration reflected public outrage that prisoners should receive educational benefits not available to our law abiding citizens. ${ }^{13}$ It is often hard to document the occurrence of carceral programs, for our prisons are often in far-flung places, out of the public view, and those doing this work often do not want a spotlight on these efforts, as society does not always see the value of educating inmates. There are, however, a number of prison theatre programs that focus on Shakespeare.

8 The pioneer Shakespeare prison program in the U.S. is the Shakespeare Behind Bars program, started as an outgrowth of the Books Behind Bars program at Luther Luckett Correctional Institution. Other programs include the Shakespeare Prison Project in 
Racine Wisconsin, Shakespeare in Prison at the Women's Huron Valley Correctional Facility in Michigan, and the programs offered by the Marin Shakespeare Company in California. ${ }^{14}$ Shakespeare prison programs are not unique to the U.S., of course, as such programs also exist in Europe and Australia. ${ }^{15}$ Each theatre director approaches the work differently, but all must negotiate carefully within the political and governmental structure of the state and the prison system, as prison wardens and rules that govern individual prisons differ according to the state regulations. My class was fortunate to have that right combination close by, in Wisconsin, where Jonathan Shailor, a professor at University of Wisconsin-Parkside, directs the Shakespeare Prison Project at the Racine Correctional Institution. Most of these artistic directors have been influenced by Paulo Freire and Augusto Boal, which provide the foundation for the pedagogical approach to their theatre training. ${ }^{16}$ Both scholars explore the impact of oppression on the development of the human being and spirit, and both see educational systems as a variant of oppression. Boal provides theatre exercises and games to shift one's thinking away from the state of oppression and to begin to build trust among the practitioners. Freire's pedagogy is grounded in the belief that the possibility of hope for change can bring students and teachers into a relationship of respect. Jonathan Shailor, for example, notes Boal's work on "helping nonactors become protagonists of their own lives by exploring their personal and social problems and then transforming them through 'a rehearsal for reality'." ${ }^{17}$ bell hooks ${ }^{18}$ describes the philosophy of hope as

progressive education, education as the practice of freedom, [that] enables us to confront feelings of loss and restore our sense of connection. It teaches us how to create community. . . [and] make the classroom a place that is life-sustaining and mind expanding, a place of liberating mutuality where teacher and student together work in partnership. ${ }^{19}$

Fundamental to the success of these programs is the concept of trust. No one in prison has reason to trust another, and in fact, most are wise not to trust. Social activists espousing prison programs grounded in some form of rehabilitative arts do not conjure ideas of hope, trust, or change among the inmates. The inmates begin from a position of distrust and believe these theatre practitioners will use them for personal or professional advantage in a form of "working the system." The success of these programs depends upon the full commitment of facilitator and participants to jointly contribute to a community of shared vulnerability. Facilitators trust the inmates' willingness to work on building relationships and to put forth the effort that leads to performance, and the inmates trust in the safety and sanctity of the process. Although these programs do not have the inmates audition for their particular role, the participants are expected to earn a spot in the program through good behavior and interest.

\section{Why Shakespeare?}

10 Artistic directors of prison theatre programs choose Shakespeare for many reasons. Prisoners are more likely than the average citizen not to have attained a high school diploma. According to data from the U.S. Bureau of Justice, $56 \%$ of federal inmates and $67 \%$ of inmates in state prisons did not complete high school. Without a high school diploma, many of these inmates read at a fourth grade level, and more than $60 \%$ of prisoners are functionally illiterate.$^{20}$ It is highly unlikely that any of the prisoners would have been exposed to Shakespeare's plays. College students majoring in English complain 
that Shakespeare is hard and his writing is complicated, so why would Shakespeare be a good choice for inmates?

The artistic director often chooses Shakespeare because his works are unfamiliar and challenging to this population. If the inmates read a contemporary text, particularly by an author from a similar ethnic or racial background, it would be too easy for the inmate to rely on lived experiences or known identities when creating a character. Shakespeare offers various distances that need to be traversed. The people, the language, and the plots often seem particularly foreign and alien upon first reading, and it is only through study and interrogation that the reader discovers the similarity to our own milieu and experiences through Shakespeare's focus on the human elements that transcend time or class. Moreover, Shakespeare is perceived as highbrow art that many reject because of the association with certain levels of education or status. Through Shakespeare, the inmates learn new words, new forms of expression, and comprehend metaphor and images in ways they discover they innately understand. The actor inmates also learn to assist each other. Kate Powers, Shakespeare director and a facilitator with Rehabilitation Through the Arts at Sing Sing Correctional Facility in Ossining, NY, has worked with inmates who cannot read but learn the lines by memorizing what others recite. ${ }^{21}$ Lesly Currier, director of the Marin Shakespeare Company, notes that

when inmates can prove they can do something as complicated, difficult and challenging as memorizing a whole Shakespeare play and performing it in front of their peers, not only is there a lot of personal transformation that's going on, but also it transforms the institution..$^{22}$

Perhaps most important, the plays tell rich and complicated stories that require any reader to think about the topics of power dynamics, jealousy and greed, bonds and trust, desire and ostracism, the very issues and emotions, through confrontation or avoidance, that may have contributed to the inmate being incarcerated. Ultimately, the inmates make a discovery of the familiar through the unfamiliar, and by engaging with the stories and emotions that are remote, they learn to develop empathy first for the created persona and eventually for the human beings surrounding them. They discover their own stories are not unique and find commonalities with others, fictional and real. The inmate who played Shylock in the production my students saw, for example, explained that as an African American Muslim, he knows how important his faith is to him in a hostile environment. He could feel Shylock's pain when forced to lose his religion and convert to the religion of his oppressors. Through this common experience, he found a way to understand and become Shylock the Jew. The men playing women often think about grandmothers, mothers, or sisters as they begin to realize what it means to be female. Sue Jennings, another prison theatre director, writes, "Shakespeare, probably more than any other playwright apart from the ancient Greeks, is able to tell a story that is relevant to everyone, even today, and to tell it in such a way that it continues to resonate." ${ }^{23}$ Jennings's argument for universality is shared among facilitators of successful Shakespeare-in-prison programs. Jonathan Shailor of the Shakespeare Prison Project states: "The strangeness, difficulty, and excellence of the plays are precisely the stimulus and the container needed by men whose emotional lives are troubled, chaotic, and volcanic. While Shakespeare's language at first seems formidably complex and alien, in time, the men make it their own, and through making it their own they find a new voice." ${ }^{24}$ The rich language provides an opportunity for the actors and directors to unpack meanings of words and connect this new vocabulary to emotions they are also discovering anew. When Iago cautions Othello "Oh, beware, my lord, of jealousy/It is the 
green-eyed monster which doth mock/The meat it feeds on" (3.3.166-168), inmates reading and discussing this metaphor learn why jealousy is more than an emotion and is instead a monster that destroys the possessor. They learn a new ways of both talking about and experiencing emotions, and through both a literally new vocabulary to speak of now familiar experiences made unfamiliar, they speak from a different heart and head. In a way, the transformation creates the double consciousness W. E. B DuBois wrote about in The Souls of Black Folk, of being "an American, a Negro; two warring ideals in one dark body," for these inmates begin to see themselves as the person who came to jail and the person they hope to become..$^{25}$ The directors of these programs know what all educators know, too: challenge our students to go beyond what our students think they are capable of doing to create pride and ownership of achievement.

In order to become part of any prison theatre project, the director requires honesty about why one is in prison and the inmate makes a commitment to hard work as an ensemble member where the group is more important than the individual is. They join not because they get points toward good behavior or because of a burning desire to perform. Most members of any of the prison programs have been incarcerated for a while, and theatre gives them something different to do each week. Word of mouth and having seen a production generates interest. The inmates must agree to certain rules: no "fixing" of others or other people's problems; being present; living in the eternal now; listening and seeing others; speaking from "I"; and the freedom from being wrong. ${ }^{26}$ If asked, most inmate artists will tell you that through performance, they have learned how to understand other people, to listen to others, to see how their story belongs also to others, and to find new solutions and ways of working through conflict. ${ }^{27} \mathrm{Hal} \mathrm{Cobb}$, an inmate at Luther Luckett explains:

Nowhere else in my life, particularly my life in corrections, am I required to reach under the surface. Nowhere else in prisons am I asked to get out of my head. No one but Curt facilitates the space to process difficult truths and encourage complete responsibilities for our choices and actions. ${ }^{28}$

Prisons dehumanize, and in keeping with the mass incarceration movement of the U.S., warehousing of humans becomes easier when the people are treated as numbers to be punished and maintained rather than as humans to rehabilitate. Jonathan Shailor describes the prison condition:

One of the bitter ironies of the U.S. prison system is that the emotions that cause people to end up in corrections - fear, detachment, hatred, anger - are often further fed by incarceration. Instead of a respite from these destructive feelings, prison tends to create a super collider for them. Prison theater programs create sanctuaries where the distractions and the degradations of the normal prison context are temporarily set aside. A safe container is established where focus and discipline can be exercised in the service of artistic goals. A sense of ensemble or community can develop, offering both challenge and support to each of the participants. $^{29}$

Casting occurs through collaborative decision-making and after the actors have an understanding of the characters. Each actor lists his top three choices, and through discussion, roles are assigned. For a culture in which vulnerability comes with a price, playing the role of a woman carries no stigma. Being the best or the most accomplished reader does not guarantee a better part. Casting is a process based on what an inmate needs and what the ensemble needs. Almost always, last minute changes occur. In our production of Merchant, one actor had to learn his part in three days when an inmate had to go into the infirmary. ${ }^{30}$ When the first Shakespeare Prison Project production of King 
Lear was performed, Professor Shailor had to perform Lear after the inmate playing Lear was sent into solitary confinement for laughing when a guard slipped and fell. ${ }^{31}$

Few of the inmates have known each other until they come together through theatre. Suddenly, inmates are working with others they may have avoided because of race. Leslie Curran, director of the program at San Quentin, recalls:

Two members of [the] class-one black, one white-[were] practicing their lines in the yard when a friend of the black inmate came up and said, 'What are you doing talking to that white guy?' 'We're studying Shakespeare,' the black actor answered. 'Oh, Shakespeare!' his accuser responded. 'That's OK.' ${ }^{32}$

Damien Brown, serving a life sentence for child abuse, noted that the acting exercises they did together

have people vulnerable..., so suddenly two men who viewed each other with deep suspicion and distrust for decades now see what they've never seen in one another. You see this soft, human moment and the flash in the eyes, the light: It must feel good to get this mask off for a minute. And when you see that, you can't unknow what you know. Then you start to see the human..$^{33}$

One would be challenged to find a better articulation of stripping the shell that has made people impervious to the pain or emotions of another human being. Brown also articulates the genuine fear of opening oneself to another human being who has the power to hurt through rejection or invalidation of another person. Curt Tofteland describes the process as "Restorative circles of reconciliation." ${ }^{34}$

Performing Shakespeare in prisons introduces or builds other audiences for Shakespeare. All prison programs depend on donations, for funds that are available for inmate education or rehabilitation are limited and often must be used for transcripted experiences. Donors who contribute to these programs often find themselves invited to a production. In addition, state legislatures or others who can influence prison funding are invited to attend a performance. Attending a production of a contemporary play lacks the gravitas of Shakespeare, who in the U.S. continues to be associated with high culture. Works considered elitist, performed by the outcasts of society, makes for an exotic experience, and this gives those in attendance a certain cachet. The other civilian members of the public performances-the families- are as unlikely as the inmates to have a familiarity with Shakespeare. Some prison productions, such as Shakespeare Behind Bars, issue a thick program that is a mini-magazine that includes full cast profiles, a history of the carceral program, inmates' insights into the play, and clear plot summaries. These members of the audience may not ever read a Shakespeare play at home or attend a play other than in the prison, but they do develop a sense of pride not only for their loved one's performance but also for the fact that their husband/wife/daughter/son/father/ mother/other relative is performing in Shakespeare.

\section{Students Attend the Production}

None of the students had read Merchant of Venice before, and none had seen any of the film versions. By the time we read this play, most of my students had come to enjoy Shakespeare. Not all the plays were equally popular, but the students contributed to lively debates in class and demonstrated a growing understanding of the actions of Shakespeare's villains, the vanity and fragility of human love, and the thorny and complex facets of understanding what justice means. My students had become 
particularly intrigued by topics of revenge, retribution, forgiveness, and reconciliation. We spent time in class exploring the historical background of the play and the circumstances of being a Jew during Shakespeare's age. They instantly liked Portia and empathized with her complaints of a meddling parent. Although initially empathic to Shylock, they were repulsed by his insistence on his pound of flesh and found this eyefor-an-eye philosophy completely unacceptable. Throughout the reading, the students had alternated between condemning Shylock and Antonio, but now they experienced the genuine dilemma of how to affix blame and condemnation on any one character when they felt conflicted about who to forgive for what and how reconciliation could occur in this society.

Jonathan Shailor, the artistic director of the Shakespeare Prison Project (SPP), and I collaborated on how my students' experience of and with the Shakespeare Prison Project would be equally beneficial to each of us. The Shakespeare Prison Project support fluctuates based on the warden and popular sentiment. For eight years, the SPP was on hiatus when the warden revoked his support because of concerns about funding and public perceptions. Public support and an understanding of how these programs benefit us all is essential. I wanted my students, certainly, to support these programs, but I also wanted them to see how and why Shakespeare matters, and not just to those fortunate enough to go to college. I also wanted my students to learn about the incarcerated.

To attend the performance, my students and I traveled approximately 90 minutes to Sturtevant, Wisconsin, a town of 6,000 in Racine County. On the night we attended Merchant, we gained a small insight into what it means to go to prison. The entrance guards were not particularly welcoming and did not invite us to wait for Professor Shailor inside and out from the rain. Guards conducted an inventory of all the costume pieces and props Professor Shailor brought in, as he removed every carefully folded and placed object out of the case for inspection, a process repeated at the end of the evening. We had been told what not to wear-open toed shoes, exposed tattoos, and even some colors are forbidden - and then had to pay for lockers to leave our personal items, such as keys, phones, watches, etc., before we would be allowed inside the prison. One student had to disrobe and leave her brassiere behind, as it was an underwire model. Once inside, we were escorted to the performance space, an all-purpose room adjoining the prison library, where several rows of plastic chairs had been arranged. We took our seats and were soon joined by fellow audience members - inmates, all - who filled in the seats in front of us, behind us, and beside us. Guards stood by on either side of the room. Then we waited.

Such performance spaces for prison drama exemplify closed systems quantifiably bound. Just as prisoners are supposed to be "repurposed" through a prison sentence, the plays take place in repurposed spaces whose original function is not disguised. There is no theatre, no auditorium, and no place to build and store a set. All is makeshift; the warden chooses the venue for the performance, such as the chapel, library, or dining hall. The performers read and rehearse according to strict regulations; the director cannot work earlier or stay later with the inmates, for all interactions are strictly timed. Each inmate's routine is highly regulated with precisely timed minutes for outdoor exercise, meals, work, leisure and sleep, all determined by those in charge. With whom one interacts is likewise determined and controlled by others. In these brief hours of performance, however, the closed system momentarily opens. Some carceral performances separate public performance from performances for the inmates and thus tightly control the 
interaction between visitors and the prisoners. At the Racine Correctional Institution, the invited public sits among the incarcerated. For those two hours, the outsider enters the prisoner's world, both that created through performance as well as the literal cellblock experience. In these special performances for guests only, such as at Luther Luckett, an intermission allows the audience to meet the actors and ask questions. We become part of the space inmates create through words, acting, simple props, and costume pieces. At the same time, these inmates create within the prison an imagined space in which they have agency.

Costumes were often pieces to suggest a role rather than to transform the inmate. Their prison garb had to remain visible at all times. Prison uniforms strip agency, erasing identity and serving as a reminder of one's lack of status. No stage or scene design transforms the place of performance. No one, actor or audience, has the luxury of forgetting these are inmates performing a part, but for those hours of a performance, the inmates experience a double consciousness of being an inmate and another human being. Although still in the uniform that strips away personal identity and dictates what can be said, to whom, and why, the inmates experience a freedom of expression usually unknown. As characters, they challenge authority, plot insurrection, declare love, admit error, and dispense forgiveness. For many performers, they are learning to express what they have not in their own lives, but they also experience a freedom to explore words and actions they could never utter or perform as the number they are as inmates. Hal Cobb, serving a life sentence without the possibility of parole at Luther Luckett notes:

When someone responsible for the death of others chooses to honestly and truthfully portray a character responsible for the death of others, he cannot avoid change at a core level. When a perpetrator of crime chooses to portray a victim of crime, he must first examine the effects of his choices on others and find a deeper personal responsibility. When individuals who have never spoken in a public forum face their fears or a stutterer stubbornly pushes through to voice the complicated syntax of a Shakespeare speech, they prove brave and courageous and find a profound self-confidence ${ }^{35}$.

Stephen Haynes, reflecting on his performance in Richard III and the Duke of Buckingham's insight that his "deep service" to Richard will only be repaid with "contempt," notes:

When someone is on the inside, it isn't easy for them to see the whole picture with clear perspective. In other words, it's hard to see ourselves as we actually are. Buckingham is forced outside and realizes, albeit too late, how deranged Richard is. Buckingham went looking for a reward. .. but like most of us, gets what he actually deserves. ${ }^{36}$

No lights were dimmed to start the production, and the fluorescent lights overhead remained at the same bright radiance throughout. An inmate played the guitar off to the side of the room, and Professor Shailor announced the beginning after welcoming the inmates and the guests. From the beginning, the actors captured our attention. Under the watchful eyes of the guards, the actors put costumes or emblems over their prison uniform. Small boxes served as caskets, and Shylock brought forth a justice scale. The acting was uneven, but some performances were outstanding, and none were bad. At one point, the man playing the French noble suitor for Portia's hand forgot his lines. An actor with autism and a speech impediment, wearing a colorful pink suit, he struggled to stay in character while recalling his words. For several moments all was quiet, and then men in the audience started shouting, "You got it." "It's okay." His fellow actors helped him 
out and he recovered. We witnessed the teamwork and humanity the program had cultivated.

During the performance, I watched my students and the inmates closely. Revealing my own snobbery, I wondered how these men would respond. I found many of them scarylarge and menacing, and the uniforms, pervasive tattoos, and environment reminded me I was surrounded by criminals. I watched a man who started viewing the play with his chair tilted backwards on the back two legs, armed crossed, slowly lean forward until he was transfixed, arms folded under his chest, as we listened and watched with intensity. Laughter erupted in the places we might expect, and at the conclusion, the entire audience leapt to its feet. The man who played Shylock, a lifer without the possibility of parole, was one of the best Shylocks I had seen. During the talkback, one of my students was first up on her feet, crying, talking about how she had never been so moved by a performance. She thanked them profusely for sharing their talent with her. One of the inmates spoke about how this was the best experience in his ten years behind bars and for the first time he momentarily forgot where he was. Before the end, we were having conversations with the performers and others in the audience, shaking hands and giving praise, none of us wanting the experience to end.

On the ride back to campus after the event, I heard my students say they had completely forgotten the performers were inmates. One student said she had been very afraid of this trip and only agreed to go because she trusted me. She came to realize that these men were just human beings who had made some bad decisions and done horrific things. These men are not petty criminals, for Racine is a Level II institution. They are pedophiles, sex crime offenders, and murderers. Many of the incarcerated are lifers. But for nine months, twice a week, and for four performances, they were actors telling a story for their community. To date, approximately 800 inmates have had some engagement with the project, on stage, behind the stage, or in front of the stage. Listening to these stories, watching men work as a team, the students came to have a deeper understanding of how we use prison as a means of revenge. They questioned how our society practices justice, and struggled with how to reconcile a family's wish for justice and retribution with what is fair and just. My students were challenged greatly to wrestle with their own conscience and the societal need for appropriate justice. How do you make sense of great talent and humanity displayed by someone who has killed another and destroyed a family? The students saw how acknowledgment of and reconciliation with one's flaws, errors, and crimes leads to repentance and redemption. Interacting with these men and watching a performance, they understood deeply the many ways in which theatre is about collaboration-between a prison system and society, between the men on the stage, and between audience and performer. They also realized why and how Shakespeare matters-a lot-in the $21^{\text {st }}$ century.

\section{NOTES}

1. http://www.shakespeare400chicago.com/events.html. Last accessed May 6, 2018 
2. http://www.chicagonow.com/chicago-eats/2016/03/shakespeare-400-culinary-completeworks-38-chicago-celebrity-chefs-take-on-the-bard. Last accessed May 6, 2018

3. The productions of Othello included a link to some clips and discussion with the Q Brothers, a Chicago-based company that adapted Othello as a rap production with four actors playing all the roles (https://www.youtube.com/watch?v=9ovjeKL_TqQ, and https://www.youtube.com/watch? v=ItPt2d5T6lU ), James Earl Jones' soliloquy at the White House (https://www.youtube.com/ watch? $v=$ _evRg7HuuSc), the filmed version of the National Theatre of Britain's production of Laurence Oliver's production (https://www.youtube.com/watch? $\mathrm{v}=\mathrm{H} 1 \mathrm{phgQ9qbIU}$ ), the more recent NT Live production (https://www.nationaltheatre.org.uk/file/othello-iago-and-othello), and the Chicago Shakespeare Theatre production from 2016 (https://www.youtube.com/watch? $\mathrm{v}=2 \mathrm{~m} 69 \mathrm{xj}$ IcKuc). The selection allowed students to hear the beauty of the language, to appreciate the importance of historical context to production, and to be reminded, again, of Shakespeare's relevance to all ages. Using the $Q$ Brothers clip allowed me to introduce early In the semester the connection between Shakespeare and prison performance, as the Q Brothers have performed in the Cook County Jail (https://www.youtube.com/watch?v=x1j06AF0ViM). The productions of As You Like It included the $1978 \mathrm{BBC}$ production, directed by Basil Coleman, the Shakespeare Globe production (https://www.youtube.com/watch?v=00qzMQgCyju), and the 2013 production at the Royal Shakespeare Theatre (https://www.youtube.com/watch?v=72pyUuNLuoE\&t=139s, https:// www.youtube.com/watch?v=qpEqv7DAPV4).

The productions of Antony and Cleopatra included 1974 Trevor Nunn Royal Shakespeare Theatre ( https://www.youtube.com/watch?v=BPc2fcxOUxE), the Iqbal Khan 2018 RSC production (DVD), and the Elizabeth Taylor and Richard Burton production from 1963 (Prime Video). I Henry IV productions included the Dominic Dromgoole 2010 Globe Theatre production (DVD) and the 2014 Gregory Doran RSC production (DVD). Merchant of Venice productions included Merchant of Venice, directed by Michael Radford, Sony Pictures and Movies, 2004; Merchant of Venice (Shakespeare's Globe, directed by Jonathan Munby, Opus Arte, 2016); RSC's Merchant of Venice, directed by Polly Findlay, Opus Arte, 2015. We also watched clips and interviews with David Suchet and Patrick Stewart (https://www.youtube.com/watch?v=FU_zqBIITDM), and interpretations of Portia ( https://www.youtube.com/watch?v=E643Vme37y0). The Tempest productions included attending "The Tempest in Cinema" live broadcast at the Music Box Theatre, Chicago, IL (Royal Shakespeare Company, directed by Gregory Doran, 2016); the Globe production, directed by Jeremy Herrin, 2014 ( https://www.youtube.com/watch?v=mo1QooWbgDc), and Derek Jarmon, 1980 US production (https://www.youtube.com/watch?v=vHi_g9gmAY0).

4. Margaret Atwood, Hagseed, Hogarth Shakespeare Series, London, Hogarth, 2016.

5. Shakespeare Behind Bars, directed by Hank Rogerson, Shout Factory, 2006

6. Curt Tofteland, Shakespeare in Prisons Conference, March 23, 2018, Old Globe Theatre, San Diego, CA.

7. Peter Wagner and Wendy Sawyer, "Mass Incarceration: The Whole Pie 2018," Prison Policy Initiative, https://www.prisonpolicy.org/reports/pie2018.html. Last accessed May 6, 2018.

8. Bureau of Justice Statistics, https://www.bjs.gov/index.cfm?ty=tp\&tid=11. Last accessed May 6, 2018

9. National Institute of Justice, https://www.nij.gov/topics/corrections/recidivism/Pages/ welcome.aspx. Last accessed May 6, 2018

10. Shakespeare Behind Bars, https://www.bjs.gov/index.cfm?ty=tp\&tid=11. Last accessed May 6, 2018

11. The first recorded performance of a professional play performed in a U.S. prison occurred in 1910. Scott Fletcher, "Marin history: Sarah Bernhardt among performers at San Quentin," Marin Independent Journal, December 24, 2018, (https://www.marinij.com/2018/12/24/marin-historysarah-bernhardt-among-performers-at-san-quentin/) Last accessed on February 6, 2019. 
12. Christopher Isherwood, "A Long Wait for Another Shot at Broadway," New York Times, April 22, 2009, online (https://archive.nytimes.com/www.nytimes.com/2009/04/26/ theater/26ishe.html). Last accessed on February 6, 2019.

13. Zaid Jilani, "How Congress Killed One of the Few Lifelines for Former Prisoners - And Why It's Time to Bring It Back," AlterNet, June 3, 2015 (https://www.alternet.org/2015/06/howcongress-killed-one-few-lifelines-former-prisoners-and-why-its-time-bring-it-back/). Last accessed February 6, 2019.

14. Shakespeare Behind Bars (https://www.shakespearebehindbars.org/), Shakespeare Prison Project (https://www.shakespeareprisonproject.com), Shakespeare in Prison Project (http:// www.detroitpublictheatre.org/shakespeareinprison/), and Marin Shakespeare Company ( https://www.marinshakespeare.org/shakespeare-in-prison/).

15. Internationally, programs exist in Italy (Rebibbia Prison), Queensland, Australia (Shakespeare Prison Project, http://www.qldshakespeare.org/prison_project.html), and throughout the UK (London Shakespeare Workout, http://www.londonshakespeare.org.uk/ and Synergy Theatre Project http://www.synergytheatreproject.co.uk/, are two examples).

16. Paulo Freire, Pedagogy of the Oppressed: Thirtieth Anniversary Edition, New York, Continuum 2000; Paulo Freire, Pedagogy of Hope: Reliving Pedagogy of the Oppressed, London, Bloomsbury, 2014; Augusto Boal, Theatre of the Oppressed, New York, Theatre Communications Group, 1985.

17. Jonathan Shailor, "Humanizing Education behind Bars: Shakespeare and the Theatre of Empowerment," Challenging the Prison-Industrial Complex: Activism, Arts, and Educational Alternatives, Stephen John Hartnett, editor, Urbana, Illinois, University of Illinois Press, 2011, p. 231.

18. bell hooks does not use capitalization for her name.

19. bell hooks, Teaching Community: A Pedagogy of Hope, New York, Routledge, 2003, p. xv.

20. http://www.begintoread.com/research/literacystatistics.html__Last accessed May 6, 2018.

21. Shakespeare in the Criminal Justice System: A Panel Discussion. Chicago Shakespeare Theatre, September 2016.

22. Story Hinckley, "Why Some California Inmates are Turning to Shakespeare," Christian Science Monitor. May 31, 2016, Online (https://www.csmonitor.com/USA/USA-Update/2016/0531/Whysome-California-inmates-are-turning-to-Shakespeare) Last accessed May 6, 2018.

23. Sue Jennings, "The Nature and Scope of Drama Therapy: Theater of Healing," Shakespeare Comes to Broadmoor, ed. Murray Cox, London, Jessica Kingsley Publishers, 1992, p. 242.

24. Jonathan Shailor, "When Muddy Flowers Bloom: The Shakespeare Project at Racine Correctional Institution." PMLA 123.3, 2008, 632-641, p. 11.

25. W.E.B. DuBois, The Souls of Black Folk, 1903, https://www.gutenberg.org/files/408/408-h/408h.htm, (accessed February 6, 2019).

26. Core values of Shakespeare Behind Bars, https://www.shakespearebehindbars.org/about/ mission/, [last accessed February 6, 2019]. Jonathan Shailor espouses similar values or rules for the Shakespeare Prison Project, “A Professor's Perspective: The Shakespeare Project at Racine Correctional Institution," Creating Behind the Razor Wire: Perspectives from Arts in Corrections in the United States, ed. Krista Brune, p. 40 (file:///C:/Users/pmona/Downloads/shailor_09.pdf).

27. Examples of this expression can be found through the documentary Shakespeare Behind Bars, directed by Hank Rogerson, Shout Factory, 2006, from reading the prisoners' statements from production playbills (https://www.shakespearebehindbars.org/wp-content/uploads/2016/09/ Twelfth-Night-Playbill-2016.pdf), and in talkbacks with the incarcerated and the returned citizens.

28. Curt L. Tofteland and Hal Cobb, "Prospero Behind Bars." Shakespeare Survey 65 (2013), 429-444, p. 437.

29. Jonathan Shailor, ed., Performing New Lives: Prison Theatre, London, Jessica Kingsley Publishers, 2011, p. 22. 
30. Talkback between the actors and the audience following the performance of Merchant of Venice, May 2017, Racine Correctional Institution, Sturtevant, Wisconsin.

31. The experience was shared with the audience, including my students, by Professor Shailor and a returned citizen, Haisan Williams, who performed in the production. "The Remarkable Journey of Haisan Williams: From Prisoner to Performer... on the World Stage," University of Wisconsin-Parkside, Kenosha, Wisconsin, March 3, 2017.

32. Sean Elder, "Why They're Doing Shakespeare in Prison," Newsweek, Dec. 11, 2016, online. http://www.newsweek.com/2016/12/23/shakespeare-prison-california-inmates-teachingstudents-530602.html. Last accessed May 6, 2018.

33. Ibid.

34. https://www.shakespearebehindbars.org/programs/pastprogramming/ottawajj._ Last accessed May 6, 2018.

35. Hal Cobb, "The Pursuit of Truth," The Observer: A Quarterly Publication. Summer 2010, p. 17.

36. Stephen Haynes, "Who's Who in the Cast," Richard III Playbill, June 13-20, 2013, Pdf. Luther Luckett Correctional Institution. www.Shakespearebehindbars.org, p. 18.

\section{ABSTRACTS}

The United States is home to the largest prison population in the world. The incarcerated too often are viewed as appropriately warehoused as they pay their debt to society. Enlightened prison wardens and artist educators know the value of using prison time to rehabilitate through education, and Shakespeare theatre programs demonstrate success at reducing recidivism rates and returning citizens to more productive lives. Introducing college students to these programs transforms the students' learning experience. The layers of collaboration-between text and performer, between performance and audience (inmates), between inmates and students, and between students and theatre-continue to evolve. This essay explores the ways in which Shakespeare unshackled by expectation-of who can appreciate the work, how it can be performed, and how the privileged and the disenfranchised can be joined by Shakespeareproduces greater insights into the plays and the human. Using voices and experiences of both inmates and students, this essay explores this unorthodox way of understanding collaboration, the ways in which an alternate performance text comes to the stage, and provides insight into how and why this approach to Shakespeare transforms a prison population and those engaged in these productions.

Les États-Unis abritent la plus importante population carcérale au monde. Les personnes incarcérées sont souvent perçues comme méritant d'être simplement mises à l'écart pour payer leur dette à la société. Mais les gardiens de prison et les artistes qui y interviennent savent et mesurent combien il est précieux d'utiliser le temps passé en prison pour entreprendre une réhabilitation par l'éducation, et les programmes de théâtre autour de Shakespeare se sont avérés utiles pour réduire les taux de récidive et aider des citoyens à retrouver des vies plus productives. Les étudiants à qui l'on présente ces programmes à l'université voient leur apprentissage transformé. Les divers niveaux de collaboration-entre le texte et les acteurs, entre les acteurs et le public (les détenus), entre les détenus et les étudiants, et entre les étudiants et le théâtre-ne cessent d'évoluer. Le présent article explore la façon dont Shakespeare, une fois débarrassé de certaines idées que l'on se fait du public capable de 
l'apprécier, de la façon de le jouer, ou de la façon dont privilégiés et prisonniers peuvent être réunis autour de son théâtre, renouvelle nos visions de son œuvre et de l'humain. Partant de témoignages et de l'expérience de détenus et d'étudiants, cet article explore, à travers ces expériences peu conventionnelles, la question de la collaboration, de l'émergence sur scène de textes alternatifs et la transformation vécue par la population carcérale aussi bien que de toutes celles et ceux qui sont impliqués dans ces mises en scène.

INDEX

Mots-clés: Citoyenneté, collaboration, pédagogie, théâtre en prison, réhabilitation

Keywords: Citizen, collaboration, pedagogy, prison theatre, rehabilitation

AUTHOR

PAMELA J. MONACO

City Colleges of Chicago-Wright College 